\title{
PERLINDUNGAN HAM DALAM SIKLUS NEGARA HUKUM
}

\author{
${ }^{1}$ Sesy Kirana,${ }^{2}$ Anita Trisiana, ${ }^{3}$ Wahyu Putri \\ Universitas Slamet Riyadi Surakarta \\ Email :whyputh@gmail.com, kiranasesy878@gmail.com
}

\begin{abstract}
Abstrak
Perlindungan HAM dalam siklus Negara Hukum. Dalam suatu kebebasan manusia memiliki sebuah artian bahwa suatu hak untuk kebebasan merupakan sesuatu yang telah dimiliki seluruh manusia sejak lahir di dunia, akan tetapi jika dilihat dari persfektif lain yang mengatakan bahwa kebebasan manusia untuk menjalani hidup memiliki standar yang berbentuk sebuah legalitas sama dengan aliran positivisme tersebut. Pasca berakhirnya pemerintahan Soeharto muncul suatu perubahan Amandemen UUD 1945 bahwa, konstitusi mengatur secara menyeluruh suatu hak asasi manusia itu dilindungi bahkan juga merupakan satu elemen yang harus terdapat juga dalam lingkup hukum, beserta kebebasan yangmendasar bagi seluruhwarga negara yang lengkap. Terdapat perlindungan HAM yang ada suatu laporan bagi negara anggota perserikatan bangsa-bangsa yang dilakukan setiap empat tahun sekali ke Dewan HAM PBB tepatnya yang berkantor pusat di Jenewa, Swiss. Hak dan Kewajiban dalam bernegarapun sudah tercatat dan harus dipatuhi disuatu negara. Di Indonesia sudah tercatat dalam Undang - Undang Nomor 12 bertentangan dengan RI. Bahwa UU tersebut adalah pengganti UU Nomor 62 Tahun 1958 yang membahas bahwa ketidaksuaian dengan perkembangan warga negara dan ketatanegaraa Republik Indonesia. Dalam suatu hukum positif itu terdapat hukum yang diberlakukan oleh negara kepada warga negaranya supaya kehidupan bermasyarakat dapat diatur sedemikian rupa.
\end{abstract}

Kata Kunci :Perlindungan HAM, Hak dalam kerangka Hukum, Kewajiban dinegara hukum, Negara hukum, Hukum positif. 


\begin{abstract}
Patronage of human rights deep nation sentence. Human rights are right that have been owned by all humans from birth in the world, back on the observe, human rights must be to comprise legality dutiful to the flow positive. After end the Soeharto Government which brought changes to the 1945 Constitution Amendment, The constitution thoroughly regulates that a human right is protected and is an element that must be included in the scope of law\& basic rights of citizens. In the protection of human rights, there to become a report for personnel of the United Nations which is conducted every four years for auniform circular motion (UN) Human RightsCouncilman, which is headquartered in Geneva, Switzerland. The rights and obligations in a state have been recorded and do obeyed in a homeland. In Indonesia, can be look in Law Number 12 of 2006 concerning RI. The laws is collection Law Number 621958 because not the accordance with the perfection of people \& there constitution the Republic Indonesia. At a positive law, there are laws that are enforced by the state to its citizens in reports of social life which are regulated in such a way.
\end{abstract}

Keywords: Human rights protection, human rights within the framework of the rule of law, rights and obligations in a rule of law, rule of law, positive law. 


\section{PENDAHULUAN}

Hak Asasi Manusia adalah suatu hak dari awal yang telah diberikan setiap individu atau warganegara yang sudah melekat sejak lahir yang diberikan langsung oleh Tuhan yang maha kuasa dan sesuatu keadilan dasar tersebut tida dapat semena mena dirampas dan dicabut oleh siapapun karena hak itu wajib dihormati, dilindung ,juga dijunjung tinggi baik negara, hukum dan, pemerintah oleh karena itu setiap manusia memiliki sebuah harkat dan martabat demi suatu kehormatan dan perlindungannya.

Internasional dalam masalah penegakan HAM. Karena sebelum Indonesia melakukan perjanjian tersebut, Indonesia pernah mendapat embargo (larangan suatu negara untuk melakukan eksport import barang tertentu ke negara lain). Perlindungan HAM dalam siklus negara hukum. Indonesia adalah suatu negara yang berdiri dalam kubu yang berstatuskan negara hukum, oleh karena itu, perlindungan \& penegakan HAM bagi warganegaranya sangatlah ditata dengan rapi karena negara Indonesia ini telah membuat suatu perjanjian.

Jika kalau dalam suatu pemerintahan di lingkup negara melanggar dan menyalahgunakan kekuasaan terhadap masyarakatnya dan muncul persoalan persoalan dalam sebuah negara hukum yang sama sekali belum terimplementasikan secara rata dan komperhensif disuatu perlindungan Hak Asasi Manusia kepada masyarakatnya. Terlihat banyaknya penyelewengan HAM berat maupun ringan yang terjadi di IndonesiaPada kurun waktu orde masa kini perlindungan HAM Indonesia telahmemulai memamerkan suatu progres dari tahun sebelumnya. Dalam suatu hukum yang berlaku sebuah tuntutan dalam melakukan penyelesaian kasus pelanggaran telah berkembang maju dan dengan itu datangnya Undang-Undang Nomor 39 Tahun 1999 yang menjelaskan tentang Hak Asasi Manusia dan lalu diikuti pula oleh munculnya UndangUndang Nomor 26 tahun 2000. Mengenai Pengadilan Hak Asasi Manusia tentang maksud dalam menjawab berbagai suatu persoalan dalam pelanggaran pelanggaran hak asasi manusiakhususnya pelanggaran hak asasi manusia berat.Disuatu tempat yang dikenal dengan Timor-Timur. Terdapat beberapa perkara yang cukup menjadi sorotan ini berkaitan dengan peristiwa Tanjung Priok dan dua perkara pelanggaran hak asasi manusia berat di Abepura Papua tidak menghasilkan keputusan yang memuaskan rasa keadilan khususnya bagi para korban pelanggaran berat tersebut. Beberapa pelanggaran HAM yang cukup berat sesuai dengan peraturan berlaku. Indonesia merupakan suatu negara berasaskan atas dasar hukumsesuai bunyi dalam perundang - undangan pasal 1 ayat 3 bahwa Indonesia ini adalah suatu negara hukum. Dan demikian Negara Indonesia wajib memberi suatu perlidungan Hak Asasi Manusia terhadap seluaruh manusia dan setiap masyarakatnya.Pandangan Hak asasi manusia di sisi konsep hukum kodrat ialah sebuah kebebasan yang sudah menjadi kodrat setiap individu, namun di satu sisi lain legalitas hak asasi manusia harus dibentuk oleh sebuah aliran positif. Maraknya perdebatan tentang penjelasan hak dasar yang dimiliki setiap individu yang telah terdapat dalam ketentuan ketatanegaraan juga dapat tergolong mempengaruhi standar yang terdapat dalam Perundang - undangan . Terakhir, ketatanegaraan pada amandemen telah menetapkan suatu keadilan warga negara agarlebih lengkap dapat dimulai dengan premis perlindungan HAM yang memiliki arti sebuah elemen yang perlu adanya sebuah perancangan tersebut yang berasal dari negara konstitusional. Dengan itu didalamnya juga tercantum seuatu yang berjudul "judicial review" terdapat dalam MK yang berfungsi sebagai sarana dalam menghindari adanya suatu aturan baru perundang-undangan yang berkaitan dalam pembahasan hak - hak dasar tersebut, hakikatnya sangatlah mutlak dimiliki oleh setiap individu yang fungsinya sebagaimana dijamin konstitusi.

Pandangan keadilan terdapat sebuah Ulasanyang terjadi dalam Mahkaman Konstitusi bahwa Hak kebebasan dalam persfektif lain meyakini memiliki konsep hukumnya yaitu sesuatu kebebasan yang melekat pada setiap individu sejak pembangunan akantetapi pandangan lain juga 
berpendapat bahwa sebenarnya hak asasi manusia seharusnya memiliki sesuatu yang berbentuk legalitas aliran positif. Perseteruan yang telah mengkaitkan HAM harus sebaik mungkin memenuhi kriteria dalam aturan ketatanegaraan bahkan tidak perlukah ulasan konstitusi tercantum dalam menberi satu titik suatu pembahasan dalam Perundang undangan. Dan samahalnya tersebut, Lingkup Amandemen telah usailah 32 tahun dalam Pemerintahan Orde Baru yang dipimpin oleh Suharto yang telah membawakan sebuah perubahan perubahan yang sangat penting UUD 1945. Selain itu, muncu berita bahwa konstitusi secara umum dan mutlak memiliki kebebasan seluruh individu lebih menyeluruh. Dalam perlindungan HAM yang terkandung di satu komposisi utama dalam aturan ketatanegaraan hukum. Setelah UUD 1945 pembantuan hak mendasar masyarakat sudah cukup komplit tersebut memiliki perbedaan musyawarah lain dalam elemen penting negara hukum dalam perlindungan hak asasi manusia. Dengan demikianlah bahwa dengan adanya ide menyantumkan aturan dalam kesamarataan keadilan dalam Perundang undangan dengan terperincidiserta "judicial review" yang terdapat pada MK untuk sarana menghindari adanya aturan baru yang berkaitan dengan hak mendasar seluruh masyarakat yang sangat dijamin dalam konstitusi sebuah ketatanegaraan.

\section{METODE}

A. Berkembangnya HAM dan awal kemunculan Hak Asasi Manusia.

Awal kemuculannya ini karena Magna Charta (kertas besar). Sebuah gagasan pernah merumuskan bahwa dalam catatan Internasional bermula saat perang dunia terjadi, saat itu kondisi sekitar banyak melibatkan pihak didunia ini yang kesamarataan keadilan tempo dulu tidak stabil dan sangat terinjak injak tanpa ada pertimbangan sedikitpun. Perpecahan dunia ke I \& II kala itu telah menemukan cara agar berprosesnya HAM agar menjadi warta bagi seluruh dunia dengan kemunculan yang berbuah hasil dari Universal Declaration of Human Right. ditetapkan bahwa saat 10
Desember tahun 1948an yang telah disetujui negara-negara lainnya yang juga ikut tergabung dalam ikatan PBB. Dan sebelum pernyataan tersebut telah muncul hal yang berkaitan bahwa telah munculnya catatan penting HAM yang lebih dulu memiliki suatu hukum universal dan asasi. Masyarakat di negara Amerika pernah menyusun sebuah naskah yang dikenal dengan Bill of Right pada tahun 1769 dan kemudian naskah tersebut dipertimbangkan oleh negara lalu naskah tersebut kemudian dijadikannya bagian dalam UUD tahun 1891. Diketahui bahwa memperjuangkan siklus HAM dunia termasuksangatlah sulit untuk terjun ke empat keturunan pertama yang terpaku substansi HAM terdapat dalam aspek hukum \& politik, reaksi kejamterhadap kebebasan hidup berdiri diatas kepemerintahan penindas hak pribadi dan selalu mengawasi seluruh perilaku kehidupan masyarakatnya dan adapula bentuk pemerintahan yang selalu memberi bekas tintadari tahun ke tahun yang dilalui pasca perpecahan dunia ke II. Dalam Negara Hukum tentunya sudah taka sing lagi terhadap ilmu pengetahuan konstitusi dari zaman purbapun sudah ada kemudian waktu inipun masih dapat bertahan juga. Meskipun sudah ada pada zaman purba dalam praktek ketatanegaraan ini masih banyak orang yang sering menebak nebak bahwa apakah sebuah negara hukum itu sudah dilakukan sepenuhnya apakah hanya fiktif belaka saja. Oleh karena itu tidakah sangat mengherankan hal tersebut, padahal tujuan yang universal mengenai konstitusi yang sudah berada di negara hukum sering terjadi suatu pelanggaran pelanggaran dalam praktek. Jika semakin kedepan masih seperti ini karakter yang dimiliki hanyalah formal - formal saja, dengan melihat kea rah lebih depan lagidapat memberi gambaran hidup yang sudah jauh berbelok kearah lain dibandingkan dengan tulisan dalam ketatanegaraanyang semata mata negara hukum bak hal yang mustahil seperti mitos. Sama halnya dengankenyataan yang belum pernah terdapat disejarah konstitusi. Terdapat rencana Negara Hukum Indonesia bahwa Profestor pernah bertuturjika penyelidikan tentang penolakan pendapat 
semata -mata hanya uraian negara hukum beasalmula dari hukum Eropa Barat.

\section{B.Perlunya HAM dalam setiap Negara.}

Beberapa waktu telah berlangsung Kegiatan Diseminasi digelar Kantor Wilayah yang dihadiri oleh seluruh Kepala Sekolah SMU, Organisasi Masyarakat, Tokoh Agama dan Tokoh Masyarakat di Kota setempat yang membahas dan mendalami suatu pembahasan yang berkaitan dengan kurangnya pemahaman HAM di kehidupan sosial dalam bermasyarakat, yang mengharuskan bahwa perlunya diadakan suatu diseminasi untuk menyebar luasan informasi yang berkaitan dengan HAM.

Mengapa negara hukum memerlukan HAM? "tanpa adanya suatuhukum HAM, akan ada seseorang yang akan bertindak semena - mena pada orang lain atau sesamanya. HAM merupakan salah satu dari contoh peradaban dimana suatu perbuatan yang dilakukan harus didasari dan diatur oleh Undang-undang"Mengenai suatu Instrumen HAM Nasional dan beberapa Unsur- unsur yang telah tertuang dalam sebuah HAM, dan serta bentuk-bentuk dari penyelewengan atau pelanggaran HAM itu sendiri. Didalam lingkup suatu negara seorang warganegara berhak atas dasar rasa aman yang diberi dan dimilikinya, Dan begitu pula hal yang dimulai darisanalah bahwa sebenarnya negaralah yang bertugas untuk melindungi hal tersebut. Konsep HAM dalam bernegara, pemerintah sangat dilarang melanggar Hak asasi rakyat namun sayangnya dalam hal ini HAM juga terbatasi oleh peraturan perundang-undangan yang telah berlaku sehingga rakyat pun tidak dapat semena-mena saat menuntut suatu perlindungan HAM. Saat inilah kita harus gencar dalam melakukan suatu penyebaran secara merata dan tertata rapi dalam HAM, hal ini dimaksud dengan karena sangat penting atas adanya peningkatan kesadaran suatu HAM untuk seluruh tingkat masyarakat, selain itu saat ini juga masih banyak masyarakat sipil serta petugas pemerintahan yang masih bingung akan dengan maksud dan tujuan HAM yang sebenarnya. Dengan memberikan sedikit informasi bahwa saat ini pemerintah secara terus menerus mengawasi dan telah membagi fungsi pengawasan suatu HAM terhadap setiap Kementerian yang terkait dan dari hal itu sendiri telah mengeluarkan sebuah undang undang dalam PerPres No.33 Tahun 2018 yang berkaitan denganperubahan atas PePres No.75 Tahun 2015 yang membahas tentang Rencana Aksi Nasional . HAM yang dimana telah ditindak lanjuti oleh setiap para Kementerian untuk memberikan suatu pemenuhan HAM bagi warga negaranya.

Perlunya suatu lindungan dalam aturan baru penegakan HAM memiliki arti dan makna bahwa seorang pelaku agar dihukum sesuai ketatanegaraan oleh negara hukum. Di negeri ini sendiri terdapat aturan penetapan yang berkaitan dengan kesamarataan keadilan, terdapat diUndangUndang Nomer 39 Tahun 1999. Bangsa ini telah ikut berpartisipasi dalam menjalin suatu komitmen agar dapat mengambil bagan garda terdepan untuk alat penjamin akan kelancaran suatu penegakan HAM.

Maksud komitmen menujuKOMNAS HAM lembaga ini suatu lembaga yang berkaitan dengan aturan hukum HAM, Negeri ini sangat tertumpu terhadap keadilan hukum, martabat yang serupa juga merupakan suatu jaminan hak asasi manusia lewat para demokratispun juga konstitusional. Dan dengan peraturan hukum perlindungan memberikan akses penegakan HAM negara hukum. Demikianlah terdapat beberapa pertimbangan mengenai pentingnya HAM agar ikut bagian peraturan hukum di Negeri ini. Terdapat sebuah penjelasan bahwa HAM yang tak lain adalah suatu hak yang dimiliki setiap individu secara mutlak dan telah ada di penjelasan ini ada pendapat lain mengenai bahwa suatu HAM juga telah mencakup suatu kebebasan, hak hidup ,dan hak bahagia. Dengan ini manusia dapat dikatakan manusia jika memiliki suatu hak dan kewajiban. HAM kepanjangan dari Hak Asasi Manusia yang setiap individu manusia berarti bahwa "Hak" diartikan keadilan \& kekuasaan atas dirinya , kata "Asasi" berarti hal mendasar yang diprioritaskan, dan jika menanyakan sebuah arti dari kata "Manusia" ini memiliki sebuah arti bahwa hal ini adalah ciptaan Tuhan yang sangat beruntung. Maka dari sanalah arti ham 
jika diartikan secara singkat memiliki sebuah arti yang bermakna hal mendasar yang diutamakan pun dimiliki seluruh individu yang ada.

\section{C.Amanah UUD 1945}

Apa sebab dari membentengi suatu peraturanHAM dalam Negara hukum, ada dari sekian argumen yang bertujuan sebagai alat gadai serta kesaksian terhadap kesamarataan keadilan hak yang sesuai perundang - undanganalenia 1 sampai 4, adalah sebagai berikut ini:

Dalam alenia pertama berbunyi demikian: 'Bahwa sesungguhnya kemerdekaan itu ialah hak segala bangsa.' dari wacana tercantum telah menyatakan kesamaan hak dan kebebasan agar dapat bertahan hidup demikian setiap individu dalam bangsa mutlak memilikinya.

Dalam alenia kedua berbunyi demikian : '...mengantarkan rakyat Indonesia ke depan pintu gerbang kemerdekaan Negara Indonesia yang merdeka, bersatu, berdaulat, adail dan makmur.' Sama dengan bunyi dari alenia kedua itulah tercantumnya suatu alat gadaian disuatu hak bidang keadilan,ekonomi, serta demokrasi.

Dalam alenia ketiga berbunyi demikian : 'Atas berkat rahmat Allah Yang Maha Kuasa...supaya berkehidupan kebangsaan yang bebas.' Penjelasan barusan memiliki sebuah artian besar untuk pengukuhan padahak agar warganegaranya mendapatkehidupanyang tentram dapat didefinisikan sebagai pemberiaan yang mutlak oleh Tuhan. Tidak satupun yang dapat melanggar atau menyeleweng terhadap hal tersebut.

Dalam alenia keempat berbunyi demikian : 'melindungi segenap bangsa Indonesia dan seluruh tumpah darah Indonesia, memajukan suatu kesejahteraan umum, mencerdaskan kehidupan bangsa Indonesia, dan Negara serta melaksanakan kesejahteraan ketertiban dunia yang berdasarkan kemerdekaan, perdamaian abadi, dan keadilan sosial'. Pernyataan ini mendefinisikan sebuah makna bahwa seluruh penduduk berwenang dalam penanggung kehidupanyang aman,merdeka, berilmu tinggi, sejahtera, kehidupan damai serta perlakuan adil. Sama halnya dasar Negara kita. Dasar Negara Indonesia ini yang tak lain adalah Pancasila yang telah ditetapkan dan dipercayai jika manusia ada karena kehendakNya yang terdapat elemen - elemen penting.

Dalam aspek pertama merupakan suatu elemen pribadi manusia keduanya adalah aspek sosial dan merakyat. Dengan demikianlah individu di Indonesia maupun di negara hukum telah memiliki suatu kegiatan khusus dalam memahami juga mengakui HAM orang lain.

\section{Menjaga Persatuan dan Kesatuan}

Di dalam negara Indonesia ini sangat diketahui Negara toleransi agama, ras, keragaman fisik,suku, budaya dan kepercayaan, oleh karena itutidak aneh jika terdapat suatu hal yang perlu diperhatikan yang tak lain adalah rawanya timbul suatu konflik. Oleh karena hal ini sepenting itulah HAM untuk dapat dibentengi hukum agar terpasangnya alat gadai HAM sebagai masyarakat yang khas akan keanekaragaman.

\section{E. Pelanggaran HAM dan pengadilan HAM}

Sudah tak asing bahwa terdapat suatu pelanggaran HAM merupakan sesuatu hal yang setiap tindakan perseorangan bahkan segerombolan termasuk juga seorang aparatur negara yang setiap perlakuan tersebut direncanakan maupun tidaknya, bahkan suatu ketledoran yang terdapat dalam hukum itu memberi satu goresan yang berkaitan mencabut HAM individu dalam perundang undangan, dengan tidak diresahkan lagi akan penyelesaian dalam hukumanyang tetera (UU No. 26/2000 tentang pengadilan HAM). Pelanggaran HAM ukuran standar yang telah dilakukan lain lagi dari bentuk pelanggaran HAM berat. Ada suatu kasus yang dikenal dengan kejahatan genosida yang merupakan suatu kejahatan yang setiap perlakuannya yang bertujuan menghancurkansebagian bahkan seluruh etnis,ras dan gerombolan agama. Demikian terdapat teror kejahatan genosida perbuatannya ini diketahui dengan melakukan sebuah aksinya dengan motif menghabisisekelompok dan korban berakhir mengidap penderitaan fisik secara 
mentalmembuat sengaja cacatpermanen dalam kehidupan yang tertumpu menghilangkan jejak keturunan yang akan terjadi dalam organisasi, bahkan sampai mengungsikan secara paksa dari organisasi tertentu ke organisasi lain yang dikutip dalam (UU No. 26/2000 tentang pengadilan HAM). Sebuah ketidakadilan terhadap manusia merupakan sesuatu yang perbuatannya tak lain dijalankan sebagai bagian suatu pemberontakan yang meluas bahwa suatu terorisme tersebut sengaja diperlihatkan secara terang terangan atau dikhususkan agar disaksikan oleh penduduk sipil yang berupa suatu tindak terosisme bayaranyang bertujuan pengusiran yang bersifat wajib dilakukan juga perenggutan kebebasan atau dengan kata lain ketidaksamarataan mendapat kebebasan kedaulatan yang tak berkemanusiaan telah mengacuhkan adanya suatu ketentuan pokok hukum internasional. Kekerasan sosialisme yang lainnya pula dan sama juga setara dengan penganiayaan yang dilakukan terhadap suatu kelompok tertentu yang dianggapnya tidak sama dengan yang dilakukan atau perkumpulan yang mereka telah memiliki suatu dasar bahwa persamaan tentang paham demokrasi atau alasan lainnya yang organisasi universal telah mengakuinya sendiri sebagai hal yang sifatnya terlarang sekali.,diidentivikasnya hukum internasional, penyekapan atau penculikan, dan kejahatan apartheid.

Seorang

penerobosaturan keadilanyang melakukan aksi oleh seorang pekerja negara maupun bukan pekerja negara terdapat pada kutipan (UU No. 26/2000 tentang pengadilan HAM). Dengan sebuah alasan tertentu, suatu tindakan bagi seorang pelanggar HAM tak diperbolehkan melakukan dan khusus diserahkan kepada aparatur negara saja untuk mengantisipasi terjadinya suatu sabotase. Melaikan terdapat seorang yang bukan aparaturNegara melanggar aturan. Dalam suatu gladibersih tindakan yang terdapat oleh seorang pelanggar Hak Asasi Manusia, bermula dari suatu investigasi, tuntutan, hingga jatuhan putusanyang terjadi pada pelanggar bersifat intoleran dan juga dalam keseksamaan. Pengadilan khusus yang dibangun untuk membahas suatu kesebandingan seorang dalam mempertahankan haknya berada tepat di lingkungan sekitar pengadilan umum. Seorang pengampu dalam pengukuhan, perkembangan, perawatan dan pemuasan HAM. Pertanggung jawaban ditanggung dan dibebankan tidak serta merta kepada Negara saja melainkan dibebankan secara bersama pada perseorangan juga yang memiliki arti lain bahwa suatu halnya dipertanggungjawabkan secara bersama untuk memahami aturan HAM. Dengan demikian suatu pelanggaran HAM horizontal tidak hanya dilaksanakan kepada negara terhadap masyarakatnya,yang tak lain juga masyarakat ke masyarakat lainnya telah didefinisikan sebagai garis sejajar.

Beberapa pengingkaran di Indonesia mengenai pelanggaran berat.

Telah tercatat kasus- kasus pengingkaran HAM berat di Indonesia yang cukup menjadi sorotan. Beberapa diantaranya adalah sesuatu yang terbilang seperti teka teki karena terbilang belum usai. Berikut contoh kasusnya pengingkaran HAM yang terjadi:

1. Pada tahun $1965-1966$ terjadi Pembantaian di Indonesia.Kejadian pembantaian dilakukan yang menjadi tersangka dengan partai komunis. Awal mula kejadian ini dilakukan di kota Jakarta lalu menyebar luas ke Jawa dan Bali kemudian meluas ke seluruh pulau - pulau lainnya alhasil sekitar 450.000 - 500.000 dibantai hingga korbanpun mencapai 3 juta orang tewas. Pada kejadian tentang penyelewengan HAM berat sampai sekarangpun masih diingat dalam benak para warganegara di bumi pertiwi ini yang dikenal dengan Gerakan 30 September(GS30/PKI).

\section{PETRUS pada tahun $1982-1986$.}

Terdapat peristiwa dengan suatu aksi PETRUS yang memiliki kepanjangan sebagai penembak misterius ini di curigai sebagai operasi bayaran yang dilakukan sekelompok rahasia pada masa jabatan Soeharto kala itu terjadi pada sekitar tahun 1980-an.aksi ini dikhawatirkan sebagai sekelompok yang beroprasi di bidang kriminalitas paling tinggi. Awal dari kemunculan ini dulunya adalah 
aksi umum yang dikatakan lumrah sebagai tindakan pengecekan terhadap pengepungan dan penghilangkan nyawa seseorang karena dianggap meresahkan ketentraman rakyat khusunya yang berada di wilayah Jawa. Pelaku - pelaku dari kejadian ini selalu diberi ke hokkian karena selalu tidak terdeteksi dan selalu saja beruntung atas penangkapan. Demikianlah terdapat suatu kemunculan suatu istilah "petrus" yang artinya adalah seorang penembak misterius, masih dalam peristiwa yang kejadian waktu itu korban dalam kejadian petrus terhitung tinggi karena telah mencapai angka 10000 korban jiwa, menurut keyakinan yang tersebar aksi ini terjadi karena dugaan terhadap para petinggi, aksi ini dilakukan secara rahasia dan tanpa sepengetahuan jabatan Panglima RI.

\section{Pembantaian Talangsari, Lampung tahun 1998.}

Pada tahun 1998 di Talangsari masa itu dikenal dengan peristiwa Talangsari 1998 yang merupakan kasus pelanggaran hak asasi manusia sulit di tempo lalu tepat di dusun Talangsari III desa rajabasa lama, way jepara pada 7 februari tahun 1989. Kejadian tersebut diduga bentrokan pada masa pemerintahan Soeharto yang berkaitan tentang pembahasan pancasila. Presiden Soeharto pada masa itu mengatakan bahwa adanya sisi baru akan dapat menjadi suatu penopang keseriusan juga pengalaman dasar negara kita. Setelah kegiatan percobaan tersebut terkenal seluruh kalangan mengira organisasi islam yang tempramen memiliki sisi emosional kepada pemerintah baru atau kalangan generasi baru pada masa itu. Dan pada akhirnya terjadilah sebuah aturan yang memancing reaksi dari sebuah kelompok yang fanatik yang ada diindonesia dan termasuk pada kelompok Warsidi yang berada di Lampung. Warsidi merupakan seorang tokoh yang ada pada saat peristiwa Talangsari pada masa itu. Pada saatdi Talangsari, Lampung, Warsidilah yang akan dijadikan sebagai imam oleh Nur hidayat dan teman - teman lainnya. Dan pada usailah saat itu terjadi pembantaian kurang lebih sekitar 130 jiwa tutup usai \& korban penganiayaan sekitar 229 jiwa yang terjadi pada Warsisi dan seluruh pengikut atau organisasinya.

\section{Aceh 1989-1998 Peristiwa Rmah Geudong.}

Terjadi penyiksaan yang tidak jelas permasalahannya itu menimpa seluruh warga di Aceh, tragedi ini didalangi oleh aparatur negara yang tak lain adalah seorang abdi negara tentara, perlakuan keji itu dilakukan pada masa kericuhan konflik yang makin menjadi - jadi. Aksinya yang tak berperikemanusiaan itu berlangsung dikediaman adat Aceh yang tepat sekali saat itu menjadi persinggahan atau markas tentara. Kediaman itu beralamat di Aceh pidie, desa kemungkiman aron, glumpang tiga.

\section{Penembakan Mahasiswa Trisakti (1998)}

Suatu peristiwa yang dikenal dengan Trisakti telah berlalu pada 12 mei 1998, menewaskan mahasiswa Trisakti karena konflik demokrasi pada pemerintahan Soeharto yang menurut para masyarakat dan pendemo soeharto harus lengser di jabatannya dalam memerintah, tetapi ditengah - tengah keriuhan itu terjadilah aksi penembakan pada mahasiswa yang menewaskan empat mahasiswa Trisakti yaitu Hery Hartono,Hafidhin Royan,Elang Mulia Lesmana, juga Hendriawan Sie. Tak hanya empat korban diatas setelah divrtifikasi terdapat beberapa puluh orang lainnya yang terluka. Sebelum penembakan berlangsunglah drama penyuluhan sampaian koruptor yang menyebabkan krisis moneter dan secara mendadak terjadinya demontrasi yang berlangsung menyulap seluruh orang terkejut memicu ketegangan antara aparatur pendemo karena terselipnya provokator yang mengambing hitamkan pendemo tersebut. Tak pikir panjangpun aparatur keamanan secara langsung melakukan penyerangan terhadap mahasiswa dengan menembakan gas air mata juga tindakan - tindakan lainnya.

\section{Penyanderaan Paksa 1997-1998.}

Peristiwa yang menimpa ktivis pada tahun 1997-1998 merupakan suatu peristiwa yang disebut penculikan \& penghilangan paktivis prodemokrasi yang berlangsung sebelum pelaksanaan pemilupun sidang tahun 
1997 bagi para MPR yang dilangsungkan tahun 1998 saat kejadian penculikan aktivis.

\section{PEMBAHASAN \\ A.Konsep Negara Hukum Berkaitan dengan Perlindungan HAM.}

Konsep hak asasi manusia dapat menyebabkan siklus perkembangan HAM yang tidak terkait dari hasil atas wewenang yang keputusanya dapat program konstitual dan rangkaian pemerintah baik secara hukum dan demikian telah dikatakan oleh Louis XIV mengatakan Letat'est Moi atau dengan kata lain disebut juga dengan kata saya adalah negara.Apabila wewenang satu pihak yang dapat mengakibatkan semena-mena,dan di indikasikan oleh Lord Acton power tends to corrupt, Absolute power corrupt totally yang didalam kutipan tersebut yang berarti bahwa (kekuasaan cenderung berlebih, dan kekuasaan mutlak sangat berlebih).Konsep rule of law terlahir dari perjuangan yang menolak sehingga memberontak dan seperti halnya rencana tersebut bertumbuh secara memberontak.Rencana pertama berpedoman dengan rancangan hukum eropa yang konstitual dan biasa disebut civil law.Sedangkan rancangan yang terakhir berpedoman dengan rancangan hukum cowmman law.Rasa keinginan untuk melakukan pembatasan yang lebih meningkat kepada wewenang.Dan dasarnya politik memiliki wewenang yang mengarah berlebih.Hal tersebut dapat dikhawatirkan menjauhkan fungsi dan peran perorangan dan masyarakat.Atas dasar tersebut keinginan yang besar agar dilakukan pengurangan wewenang secara lebih ketat sampai normal untuk dapat menjauhi pejabat yang absolut.Dari awal UU menjadi sangat berperan bagi kehidupan masyarakat.UU akan menjadi pembentukan hukum yang teratas dan harus ditaati oleh pemerintah dan Negara yang wajib disesuaikan bersama kamus government by laws, not by men (pemerintahan berdasarkan hukum bukan berdasarkan manusia).Di era sekarang ini yang terkesan baru dengan rancangan pemerintah yang dikembangkan oleh
Immanuel Immanuel Kant, Paul Laband, Julius Stahl.

Julius Stahl mengemukakan rancangan pemerintah tersebut dengan istilah rechtsstaat itu memiliki suatu bagian yang penting,yaitu:

1. Perlindungan dan penjagaan HAM

2. Pemerintah yang adil

3. Pemerintahan berdasarkan UU

4. Keadilan pada ketatanegaraan

Dibandingkan A.V. chancy menyimpulkan dengan ciri penting dalam setiap pemerintah rule disebutnya dengan istilah The Rule of Law, yaitu:

1. Mastery of law

2. Equality before the law

3. Group action of law

Pada dasarnya konsep tersebut dapat digabungkan menjadi satu bagian dan ditambah lagi dengan adanya gagasan pemerintah,gagasan peradilan bebas dan netral (independence and inclination of judiciary, The International Commission of Jurist.Dalam pembahasan HAM mungkinkah dapat mencangkup informasi dengan benar agar tidak tertinggal arti adanya HAM.Maka itulah sangat penting kita memperlajari sejarah HAM dan banyak pertanyaan yang layak untuk diajukan agar kita dapat mengetahui sejarah dan mempelajari HAM sehingga dapat memicu suatu perdebatan yang dapat membuat suasana semakin memperkeruh,karena sering terjadi kesalah pahaman dan penyalahgunaan isu HAM.Padahal,di sejarah kita memberikan info info mengenai awal mula terbentuknya dan kemunculan HAM sebagai wadah dan gagasan sehingga dapat dimanfaatkan menjadi sebuah standar dan constellation umum dalam berjalanya waktu suatu perkembangan dan terlihat bahkan sejumlah instrumen hukum dengan mudah dan dapat mengajukan beberapa hal untuk menjadi persyaratan Negara lain yang sudah terikat untuk merumuskan dalam suatu peraturan perundang undanganya.Dan dari konteks ruang tersebut ke indonesiaan ini,maka accelerator baiknya suatu tanggung jawab dan kewajiban Negara dapat mewujudkan HAM dan langkah yang efektif dalam bidang hukum,politik,ekonomi,sosial dan budaya,pertahanan dan keamanan.Terdapat 
penjelasan bahwa HAM yang tak lain adalah keistimewaan yang diberikan oleh tuha sejak lahir dalam penjelasan ini pendapat lain mengenai bahwa suatu HAM juga telah mencangkup suatu kebebasan,hak hidup,dan hak bahagia.Dengan ini manusia dapat dikatakan memiliki suatu hak dan kewajiban.HAM memiliki sebuah singkatan dari hak asasi manusia yang dimana setiap manusia memiliki sebuah arti bahwa kata "Hak" ini dapat diartikan sebagai kekuasaan atau hak milik atas sesuatu pada dirinya sendiri,dan "Asasi" sebagai sesuatu hal yang sangat mendasar dan utama,dan jika menanyakan sebuah arti dari kata "Manusia" ini memiliki sebuah arti bahwa hal ini adalah ciptaan Tuhan yang sangat beruntung.Maka dari itu arti HAM jika diartikan secara singkat memiliki sebuah arti yang bermakna adalah pokok utama dan mendasar disetiap manusia.

\section{B.Ciri dan unsur Negara Hukum}

Menurut Sudargo Siddhartha ada tiga ciri dan unsure dari Negara hukum yaitu :

a) Adanya batasan kebijakan pada individu,yang artinya pemerintah tidak bisa semena-mena.

b) Di suatu negara ada tindakan berdasarkan hukum tersebut ada dan yang sudah ada dan wajib dilakukan oleh badan pemerintahan dan bawahanya.

c) Pembatasan wewenang harus betul dilindungi supaya badan yang membuat UU dapat melaksaknakan dan menghakimi secara terpisah dan tidak dalam satu tangan.

Juri Asia Tenggara dan Pasifik yang terdapat dalam buku "The Dymanics Aspects of the rule of law within the fashionable Age",yang di munculkan sebagai syarat rule of law yaitu:

a) Penjagaan UU yang artinya UU melindungi hak perorangan menetapkan Botswana monetary unit yang cara prosedurnya agar mendapat perlindungan yang menjamin.

b) pengadilan tidak memihak dan bebas

c) Kebebasan dalam berpendapat

d) Kebebasan dalam beropsisi dan

e) berorganisasi

f) Pendidikan dasar (kewarganegaraan)

\section{C.Tujuan Negara Hukum}

Persoalan tentang kekuasaan tidak lain dari permasalahan Negara hukum.Terdapat dua sentra kekuasaan.Disebuah Negara terdapat wewenang yang menjadikan syarat baku untuk dapat memerintah dan selain itu terlihat rakyat yang diminta dengan semena mena untuk melepaskan segala kekuasaanya.Kita melihat apabila penguasa disebuah tempat untuk kepentingan sendiri yang besar tanpa memperdulikan rakyat,oleh karena itu hilanglah pemerintah.bersama itu terjadilah pentingnya sebuah sasaransuatu daerah yang berkaitan bersama masalah kita.Apeldoorn mengatan hukum untuk menjalankan aturan rakyat secara sama.Kedamaian antara ditegaskanoleh badan negara yang menjaga hah-hak rakyat,kebebasan orang,kehoramatan,dan yang lainya yang dapat merugikanya.keperluan individu dan keperluan orang lain yang berbedabeda.Perdebatan tujuan tersebut dapat memyebabkan pertikaian.Apabila pertikaian satu sama lain ,maka badan tersebut tidak akan berberguana untuk perantara yang akan sebagai pedoman kedamaian.aturan akan berpihak melihat keperluan dianatara hukum karena dapat mecapai tujuan (membina hidup secara damai dan menjaga perdamaian) kalau mereka menjalankan aturan yang merata.jelasnya aturan memiliki kesepadanan diantara yang akan dilindungi oleh setiap orang sehingga mendapatkan sebesar kemungkinan yang akan menjadi bagianya.Menurut Montesque pemerintah ialah Negara yang terbaik,karena didalam hukum memiliki beberapa elemen penting pokok yaitu:

a) penjagaan hak asasi manusia

b) Telah ditetapkanya suatu struktur negara

c) Menghambat wewenang dan kekuasaan badan Negara.

Hukum dapat dipastikan akan makin dianggap menjadi penting apabila ajaran Negara berdasarkan hukum dikaitkan dan menajadi pengetahuan pengetahuan yang sangat dasar didalam ilmu hukum yang akan menyatakan 
hukum tertulis lebih menjamin dibandingkan dengan hukum tidak tertulis.

\section{D.Kaitanya Negara hukum dan HAM}

Hubungan antara permerintah dan HAM sangatlah erat.HAM ialah keistimewaan pada manusia sejak ia hidup dan wajib dihargai,oleh karena itu dijaga oleh pemerintah,hokum dan semua manusia demi keadilan bersama.didasari oleh wewenang. hokum ialah konsep Negara hukum.

Yang berdaulat ialah hukum.Negara merupakan dasar hukum,arti didalam rechtstaat (badan hukum republic).Apabila bersalah akan dituntut di diadili atas tindakanya yang menyalahi aturan.Demikian juga semua ketentuan akan dilaksanakan negara yang didasari aturan.tanpa ketentuan yang akan didasari oleh aturan.Ungkapan tersebut disimpulkan bahwa setiap kaitan hak asasi manusia dan pemerintah.Didalam penegasan HAM yang wajib dilandasi ileh peraturan ,yaitu peraturan UU.Penegakan HAM didalam Negara yang berdasarkan hukum dan memperhatikan aturan yang sudah ditetapkan.Apabila negara melakukan bersama kekuasaan,dengan itu orang yang terjerat didalam pemerintahan itu akan mendapatkan hukuman. Namun,apabila bertolak belakang dengan aturan UU yang berlaku saat ini.Konsep Negara hukum yang dijelaskan dalam hubungan yang lainya dijelaskan mengenai Negara hukum mempunya ciri khas yaitu masyarakat yang harus diberikan perlindungan HAM secara adil.Maka dari itu jika disalah gunakan dan bertentangan dengan dasar Negara itu.

\section{E.Penegakan dan perlindungan HAM di Indonesia .}

Sesuatu yang secara langsung dapat di perhatikan ialah terdapat badan pemerintah yang ditujukan ditugaskan melindungi (HAM), contoh KPAI,KOMNASHAM,badan yang melindungi korban dan sanksi.Selain itu,Negara memprogram system pemerintahan pemabaharuan huku. itu peraturan perundang undangan yang memerintahkan melindungi ham yang tertulis di UU no.39 1999 mengenai (HAM),UU no.26 2000 membahas keadilan ham yang membuat rakyat negara akan lebih terlindungi haknya.

Tetapi disisi lain tersebut,masih banyak terdapat kekuranagan dan wajib dibenahi lagi oleh badan negara.Kelemahan itu besarnya penerapan.aturan tersebut banyak yang tidak bisa di implementasikan dengan tujuan oleh pemerintah jika tidak badan yang sudah dibentukuntuk melindungi HAM. individu yang dapat difungsikan dengan benar.Supaya lembaga yang dibuat tidak sia-sia dan bukan sebagai pajangan system tatanan Negara dan terus berguna bagi masyarakat Negara

\section{F.Jenis-Jenis Hak Asasi Manusia (HAM) \\ - pribadiHuman Right (Hak Asasi Pribadi) adalah suatu hak berkaitan dengan kehidupan individu setiap orang.Seperti,hak untuk berpergian,teleport,dan freedom of speech}

- Politic Right (Hak Asasi Politik) adalah hak yang saling berkaitan didalam hidup pribadi orang.Seperti halnya dalam keikutsertaan organisasi maupun pemerintah,hak dipilih dan memilih, hak dalam membuat petisi dan lainya.

- Right property yaitu suatu yang berkaitan dengan hak seseorang dalam perekonomian.Seperti contohnya penyelenggaraan sewa menyewa,memliki sesuatu dan memiliki pekerjaan yang pantas,kebebasan dalam hal jual beli,dan perjanjian kontrak.

- Procedural Right (Hak Asasi Peradilan)yaitu hak yang didalam tata cara pengadilan.Seperti contohnya sesuatu yang didapat untuk melakukan tidakan

memeriksa,menangkap,penyelidikan, membongkar,dan hak untuk mendapatkan pembelaan hukum.

- Sosial Culture Right (Hak Asasi Sosial Budaya) yaitu berkaitan tentang kehidupan masyarakat.Seperti halnya mendapat pelajaran berbudaya, seuai dengan keinginan, dan hak untuk menentukan,memilih,dan melakukan pendidikan. 
- Legal Equality Right (Hak Asasi Hukum) merupakan kebebasan mendapatkan kesetaraan di semua bidang.misalnya ialah diperlakukan secara adil didalam keadilan,pemerintahan, menjadikan pejabat,mengatur dan menjalankan kewajiban

\section{G.Ciri-Ciri Hak Asasi Manusia}

- Hak Asasi Manusia tidak diperuntukan untuk suatu kalangan,ekonomi,social, budaya,dan ketatanegaraan.

- Keistimewaan setiap individu tidak dapat dihilangkan,diserahkan, maupun dicabut.

- (HAM) bersifat menyeluruh dan dimiliki seluruh manusia tidak ada perbedaan,status,dan perbedaan lainya.

(HAM) mempunyai sifat yang sangat mutlak yaitu dari dia hidup dan masih didalam kandungan.

\section{SIMPULAN}

Nilai,konsep,dan norma merupakan pemahaman Hak Asasi Manusia (HAM) yang hidup dan berkembang didalam suatu Negara yang masyarakatnya dapat diketahui belajar sejarah Hak Asasi Manusia.hal itu juga dicatat bagian penting mengenai perkembangan pengagungan,penyesuaian Hak Asasi Manusia di sebuah tempat.menjadikan hal penting yang merupakan tentang pemahaman hak dalam Negara hokum dapat dijadikan sebagai pedoman dalam membuat peraturan supaya dapat terwujudnya pembentukan berdasarkan hak asasi.

Banyaknya beberapa hal yang berpengaruh dan berkaitan dengan suatu Negara internasional yang dalam masalah penegasan,perlindungan ham mengenai siklus Negara hukum,dan telah terbukti bahwa masih banyak penyelewengan ham yang berat maupun ringan yang terjadi Indonesia.Pada zaman sekarang penegasan ham yang ada diindonesia mulai menunjukan suatu kemajuan dari tahun sebelumnya.Dengan hal ini yang berkaitan dengan penanganan hak istimewa yang diartikan untuk menyelesaikan permasalahan penyalahgunaan ham yang digunakan untuk pelnggaran ham yang berat.Disebuah tempat yang dikenal dengan timor-timur.Terdapa bebrapa perkara yang cukup mnjadi sorotan ini bekaitan dengan kejadian Tanjung Priok dan dua masalah pelanggaran ham yang besar disuatu tempat dan nihil hasilnya dan tidak memuaskan dengan keadilan untuk orang yang dilanggar haknya.Beberapa pelanggaran (HAM) juga mengenai hukum yang cukup berat sesuai dengan peraturan yang berlaku .Demikian ini Negara Indonesia wajib memberikan sebuah perlindungan(HAM) untuk masyarakat idonesia dan seluruh manusia.

Yang dimulainya dengan kemunculan Magna Charta . Sebuah gagasan pernah merumuskan bahwa dalam naskah Internasional bermula dari perang dunia yang saat itu kondisi sekitar banyak melibatkan pihak didunia ini dan hak asasi manusia saat itu sangat tidak stabil dan sangat terinjak injak tanpa ada pertimbangan sedikitpun dari pihak tersebut. Maka dari itu Perlunya ham dalam setiap Negara, dan perlunya sebuah alasan Mengapa negara hukum memerlukan HAM.

Dengan memberikan sedikit informasi bahwa saat ini pemerintah secara terus menerus mengawasi dan telah membagi fungsi pengawasan suatu HAM terhadap setiap Kementerian yang terkait dan dari hal itu sendiri telah mengeluarkan PerPres No. 75 Tahun 2015 yang membahas tentang Rencana Aksi Nasional . HAM yang dimana telah ditindak lanjuti oleh setiap para Kementerian untuk memberikan suatu pemenuhan HAM bagi warga negaranya.

Dibentuknya pengadilan hak asasi manusia (HAM) bukan hanya untuk kebutuhan yang nasional saja,dan mengatur hukuman bagi pelanggar hak asasi manusia (HAM) ringan,tetapi juga untuk memenuhi masyarakat nasional.Demikian itu mengapa hak asasi manusia perlu untuk dilindungi,supaya teganya HAM memberikan jaminan warga Indonesia yang beraneka ragam.Dasarnya ,sebuah politik mwmiliki kekuasaaj yang cenderung berlebih.Dikhawatirkan hal ini akan 
menjauhkan fungsi dan peran Negara bagi kehidupan perorangan maupun masyarakat.Dari sebuah dasar tersebut,terdapat keinginan yang bnayak supaya dilakukanya pembatasan kekuasaan secara mendasar untuk menghindari penguasa yang otorite.

Kekuasaan terpisah supaya hak yang bisa terlindungi ialah dengan pemisahan lembaga yang merancang UU,tidak berada dalam satu tangan,dan menghakimi secara tersendiri dngan lainya.Terdapat sebuah masalah yang terdapat disuatu daerah dan dasarnya yaitu dari perbedaan kekuatan antar Negara yang menjadikan mudah menguasai Negara lainya.sebaliknya terlihat yang lemah diperbudak sangat takut menghilankan segala kekuasaanya. Dengan demikian,aturan tersebut memiliki keteraturan diantara hak yg dimiliki setiap orang yang akan dipertahankan oleh setiap orang sehingga memperoleh sebesar mungkin yang akan menjadi bagianya.Dan ditetapkanya sebuah Negara harus membatasi wewenang dan kekuasaan bagian Negara.

Yang berdaulat ialah hukum.Negara merupakan dasar hukum,arti didalam rechtstaat (badan hukum republic).Apabila bersalah akan dituntut karena melakukan pelanggaran yang menyalahi aturan hukum.Demikian juga semua ketentuan akan dilaksanakan aparat negara yang dilaksanakan atas dasar hukum.tanpa kebijakan yang akan didasari aturan yg baerlaku.Uangkapan tersebut disimpulkan bahwa setiapkaitan hak asasi manusia dan Negara demokrasi.Didalam penegasan HAM diwajibkan dilandasi ileh peraturan ,yaitu peraturan UU.Penegakan HAM didalam aparat negara yang berdasarkan aturan,wajib memperhatiakan aturan yang berlaku.Apabila aparat negara melakukan kewenangan,dengan itu individu tersebut didalam pengatur negara mendapatkan sanksi.Namun,apabila bertolak belakang dengan aturan yang sudah ditetapkan saat ini.Konsep Negara hukun yang dijelaskan dalam hubungan yang lainya dikatakan bahwa Negara tersebut mempunyai cirri-ciri yaitu masyarakatnya yang diberikan kebebasan kemanusiaan secara adil.Maka dari itu jika disalahgunakan akan bertolak belakang dengan aturan yg ditetapkan suatu negara.

Tetapi disamping kemajuan tersebut,akan masih banyak yang harus dikembangkan oleh pemerintah.Kelemahannya adalah besarnya proses penerapanya.Aturan tersebut tidak dapat diterapkan secara tepat oleh lembaga penegak hukum.Selain itu lembaga dibuat untuk melindungi hak asasi manusia (HAM) individu yang dapat difungsikan dengan benar.Supaya lembaga yang dibuat tidak siasia system tatanan negara dan terus berfungsi demi kepentingan masyarakat Indonesia.

\section{DAFTAR PUSTAKA}

Didi Nazmi Yunas, SH, 1992, Konsepsi Negara Hukum, Angkasa Raya.

Raja Grafindo Persada, 2008, h.294Ibid, h. 275Ibid, h.

Hak Asasi Manusia: Sejarah, Teori, dan

Praktek dalam Pergaulan

Internasional,

Grafiti Jakarta Scott Davidson. 1994Tim Kajian Amandemen Fakultas Hukum

Universitas Brawijaya, Amandemen UUD 1945. Cetakan ke-Sinar Grafika, 2000.

UU No 39 Tahun 1999 tentang Hak Asasi Manusia.

Makalah disampaikan pada saat bimbingan teknis HAM Kantor Wilayah Kementrian Hukum dan HAM Jambi di Hotel Ceria

Jambi tgl 24 Mei 2011.Tentang Istilah Hak Asasi Manusia

Madja EL muhtaj,Hak Asasi Manusia dalam Konstitusi Indonesia,Prenada Media,Jakarta 2005

Fadjar A Mukhtie,Tipe Negara Hukum,Malang : Banyumedia Instrans, 2004 